\title{
Association of TYK2 rs34536443 polymorphism with Susceptibility to Systemic Lupus Erythematous in the Iranian Population
}

\author{
Seyedeh Tahereh Faezi ${ }^{1}$, Samaneh Soltani ${ }^{1}$, Mahmoud Akbarian ${ }^{1}$, Saeed Aslani ${ }^{1}$, Elham Hamzeh ${ }^{1}$, \\ Ahmadreza Jamshidi', Nooshin Ahmadzadeh ${ }^{1}$, Mahdi Mahmoudi ${ }^{*}$
}

${ }^{1}$ Rheumatology Research Center, Tehran University of Medical Sciences, Tehran, Iran

\begin{abstract}
Systemic lupus erythematous (SLE) is a multifactorial autoimmune disorder which affects many organs and displays various symptoms. Genetic components contribute to the incidence and development of SLE. A rare functional variant within the tyrosine kinase 2 (TYK2) gene (rs34536443) is a common genetic candidate for several autoimmune diseases, including SLE. This case control study was performed to investigate the possible association of TYK2 single nucleotide polymorphism (SNP) with a predisposition for and clinical features of SLE in the Iranian population.

Genotyping was conducted on 600 patients with SLE and 600 sex-, age- and ethnicity-matched control subjects from the Iranian population. Patient and control samples were genotyped for one SNP (rs34536443) by applying allelic discrimination real-time PCR.

Statistical analysis of the allele distribution revealed no significant association $(\mathrm{OR}=0.67, \mathrm{CI}: 0.38-1.17, P$ value $=0.163)$ between the rs34536443 C allele and susceptibility to SLE. The CC genotype was not detected in either the patients or controls. Moreover, the CG genotypes showed no significant association with the risk of SLE $(\mathrm{OR}=0.66, \mathrm{CI}: 0.37-1.72, P$ value $=0.15)$.

These findings suggest that TYK2 rs34536443 is not associated with SLE susceptibility in the Iranian population. Further investigation is required to examine the mechanisms by which polymorphisms in this gene lead to SLE development.
\end{abstract}

Keywords: autoimmunity, polymorphism, systemic lupus erythematous, TYK2

\section{Introduction-}

Systemic lupus erythematous (SLE) is a prototypic systemic autoimmune disease that is characterized by the production of multiple autoantibodies against self-antigens owing to a breakdown in self-tolerance [1]. One important characteristic of SLE is the high female to male ratio. The pathogenesis of SLE is complex and recent evidence suggests that its etiology encompasses both genetic risk factors and environmental factors [2]. Although the exact pathogenesis of SLE remains unclear, increased understanding of the underlying genetic background of SLE can help improve the prognosis for SLE.

Several studies have pointed to the significance of the type I interferon (IFN) pathway in SLE pathogenesis [3-6]. SLE patients have been shown to have increased serum IFN- $\alpha$ levels; thus, the production of type I IFN may be important to the etiology of SLE [7]. The ligation of type I IFN with its receptor activates the IFN- $\alpha$ receptor (IFNAR), Janus kinases (JAK) 1 and tyrosine kinase (TYK) 2 and signal transcription factors such as the signal transducer and activator of transcription (STAT) [8]. TYK2 (MIM 176941; gene ID 7297), a large multidomain kinase, is the first member of JAK family, spans $27.9 \mathrm{~kb}$ nucleotides and comprises 25 exons. It is located on chromosome 19p13.2 in humans and on chromosome 9 in mice [9].

The role of TYK 2 gene in the development of autoimmune and inflammatory diseases such as Crohn's disease (CD) [10], endometriosis-related infertility (ERI) [11], multiple sclerosis (MS) [12], rheumatoid arthritis (RA) [13, 14], systemic sclerosis (SSc) [13], Behçet's disease (BD) [15] and SLE [2, 9, 16-21] has been demonstrated. Several variants of TYK2 have been investigated [22]. One rare variant of the TYK2 gene, rs34536443 single nucleotide polymorphism (SNP) causes the substitution of G to a $\mathrm{C}$ nucleotide in TYK2, resulting in a Pro1104Ala (P1104A) variation in the TYK2 protein. It has been suggested that this alteration may cause a conformational change that may affect the folding and function of TYK2 protein [23, 24]. The associ-

Personal non-commercial use only.Rheumatology Research Journal. Copyright (C) 2018. All rights reserved

*Corresponding Author: Mahdi Mahmoudi, Ph.D., Rheumatology Research Center, Shariati Hospital, Kargar Ave., Tehran, Iran. Email:mahmoudim@tums.ac.ir, Tel/Fax: (+98) 218-822-0067, PO-BOX: 1411713137,

Received: 09 June 2018; Accepted: 26 August 2018 
ation of TYK2 gene rs34536443 SNP has been linked with the risk [22] of MS [12, 23, 25], RA [26], ERI [27], SSc [13] and psoriasis [28]. Moreover, it has been shown that two naturally occurring variants of TYK2, I684S (rs 12720356) and P1104A (rs34536443) cause profound defects in basal and IFN- $\alpha$-induced autophosphorylation [29].

Because of the involvement of TYK2 in the pathogenesis of some autoimmune diseases, the current study was undertaken to investigate the functional impact of one TYK2 disease-associated variant, SNP rs34536443, in SLE patients. The association of this polymorphism and clinical manifestations of SLE also were investigated. It is hoped that the results obtained from this study enhance understanding of the pathogenesis and therapeutic strategies for systemic autoimmune diseases, especially SLE.

\section{Materials and Methods}

\section{Population and sample preparation}

In the present case-control study, SLE patients who met American College of Rheumatology [30] criteria were enlisted from cases referring to the rheumatology clinic of Shariati Hospital in Tehran, Iran. Healthy subjects were matched with the case group with respect to age, sex, and ethnicity. This study was approved by the local ethical committee of Tehran University of Medical Sciences. Before blood sampling, written informed consent was obtained from each participant. Genotyping was conducted on the 600 SLE subjects. Table 1 shows the clinical data of 235 SLE patients (18 men with a mean age of $37.6 \pm$ 13.6 years and 217 women with a mean age of $39.1 \pm 11.4$ years). The control group comprised 600 healthy matched controls with no clinical evidence or history of any type of autoimmune disease.

Table 1. Clinical specifications of SLE patients.

\begin{tabular}{|c|c|c|}
\hline Characteristic & Yes & No \\
\hline Serositis & $6(2.6 \%)$ & $229(97.4 \%)$ \\
\hline Malar rash & $147(2.6 \%)$ & $88(37.4 \%)$ \\
\hline Palmar erythema & $21(8.9 \%)$ & $214(91.1 \%)$ \\
\hline Vasculitic ulcers & $15(6.4 \%)$ & $220(93.6 \%)$ \\
\hline Discoid rash & $30(12.8 \%)$ & $204(86.8 \%)$ \\
\hline Mucosal lesion & $105(44.7 \%)$ & $129(54.9 \%)$ \\
\hline Photosensivity & $144(61 \%)$ & $91(38.7 \%)$ \\
\hline Musculoskeletal arthritis & $170(3 \%)$ & $65(27.7 \%)$ \\
\hline Aseptic necrosis & $14(6 \%)$ & $221(94 \%)$ \\
\hline Muscle weakness & $37(15.7 \%)$ & $198(84.3 \%)$ \\
\hline Raised muscle enzyme & $26(11.1 \%)$ & $209(88.9 \%)$ \\
\hline Muscle biopsy myositis & $6(2.6 \%)$ & $228(97 \%)$ \\
\hline Cast & $29(12.3 \%)$ & $205(87.2 \%)$ \\
\hline Hematuria & $89(37.9 \%)$ & $146(91.9 \%)$ \\
\hline Raised Creatinine & $19(8.1 \%)$ & $216(91.9 \%)$ \\
\hline Hypertension & $44(18.7 \%)$ & $191(81.3 \%)$ \\
\hline Renal biopsy-Class1 & $0(0 \%)$ & $235(100 \%)$ \\
\hline Renal biopsy-Class2 & $12(5.1 \%)$ & $223(94.9 \%)$ \\
\hline Renal biopsy-Class3 & $16(6.8 \%)$ & $219(93.2 \%)$ \\
\hline Renal biopsy-Class 4 & $37(15.7 \%)$ & $198(84.3 \%)$ \\
\hline Renal biopsy-Class5 & $12(5.1 \%)$ & $223(94.9 \%)$ \\
\hline Renal biopsy-Class6 & $1(0.4 \%)$ & $234(99.6 \%)$ \\
\hline Pericarditis & $16(6.8 \%)$ & $219(93.2 \%)$ \\
\hline Cardiomyopathy & $2(0.9 \%)$ & $223(94.9 \%)$ \\
\hline Libman sack & $1(0.4 \%)$ & $234(99.6 \%)$ \\
\hline
\end{tabular}




\begin{tabular}{|c|c|c|}
\hline Characteristic & Yes & No \\
\hline Valvular lesion & $35(14.9 \%)$ & $200(85.1 \%)$ \\
\hline Ischemic heart disease & $2(0.85 \%)$ & $233(99.1 \%)$ \\
\hline Raynaud syndrome & $42(17.9 \%)$ & $193(82.1 \%)$ \\
\hline Thrombophlebitis & $6(2.6 \%)$ & $229(97.4 \%)$ \\
\hline Pleuritis & $32(13.6 \%)$ & $203(86.4 \%)$ \\
\hline Lupus pneumonitis & $5(2.1 \%)$ & $230(97.9 \%)$ \\
\hline Interstitial fibrosis & $0(0 \%)$ & $235(100 \%)$ \\
\hline Pulmonary hypertension & $2(0.9 \%)$ & $233(99.1 \%)$ \\
\hline Embolism & $3(1.3 \%)$ & $232(98.7 \%)$ \\
\hline Convulsion & $28(11.9 \%)$ & $207(88.1 \%)$ \\
\hline Psychosis & $5(2.1 \%)$ & $230(97.9 \%)$ \\
\hline Peripheral neuropathy & $18(7.7 \%)$ & $217(92.3 \%)$ \\
\hline Central involvement & $10(4.3 \%)$ & $225(95.7 \%)$ \\
\hline Raised hepatic enzyme & $200(85.1 \%)$ & $35(14.9 \%)$ \\
\hline Hepatitis & $1(0.4 \%)$ & $234(99.6 \%)$ \\
\hline Sjögren Syndrome & $1(0.4 \%)$ & $234(99.6 \%)$ \\
\hline Retinitis & $1(0.4 \%)$ & $234(99.6 \%)$ \\
\hline Leukopenia & $84(35.7 \%)$ & $209(88.9 \%)$ \\
\hline Lymphopenia & $26(11.1 \%)$ & $167(71.1 \%)$ \\
\hline Thrombocytopenia & $48(20.4 \%)$ & $187(79.6 \%)$ \\
\hline Anemia & $73(31.1 \%)$ & $162(68.9 \%)$ \\
\hline Hemolytic anemia & $12(5.1 \%)$ & $223(94.9 \%)$ \\
\hline Coombs test & $42(17.9 \%)$ & $193(82.1 \%)$ \\
\hline C Reactive Protein & $157(66.8 \%)$ & $78(32.2 \%)$ \\
\hline FANA & $201(85.5 \%)$ & $34(14.5 \%)$ \\
\hline Anti-dsDNA & $200(85.1 \%)$ & $35(14.9 \%)$ \\
\hline Low_CH50 & $56(23.8 \%)$ & $179(76.2 \%)$ \\
\hline Low_C3 & $106(45.1 \%)$ & $129(54.9 \%)$ \\
\hline Low_C4 & $114(48.5 \%)$ & $121(51.5 \%)$ \\
\hline Antimalarial drug & $234(99.6 \%)$ & $1(0.4 \%)$ \\
\hline Plasmapheresis & $0(0 \%)$ & $235(100 \%)$ \\
\hline Anti-SSA & $3(1.3 \%)$ & $232(98.7 \%)$ \\
\hline Anti-SSB & $0(0 \%)$ & $235(100 \%)$ \\
\hline Positive anticardiolipin IgG & $6(2.6 \%)$ & $229(97.4 \%)$ \\
\hline Positive anticardiolipin IgM & $5(2.1 \%)$ & $230(97.9 \%)$ \\
\hline Positive lupus anticoagulant & $3(1.3 \%)$ & $232(98.7 \%)$ \\
\hline Anti- $\beta 2 \mathrm{GP} 1 \lg \mathrm{G}$ & $3(1.3 \%)$ & $232(98.7 \%)$ \\
\hline Anti- $\beta 2 \mathrm{GP} 1 \operatorname{lgM}$ & $0(0 \%)$ & $235(100 \%)$ \\
\hline IVIG & $2(0.9 \%)$ & $233(99.1 \%)$ \\
\hline
\end{tabular}




\section{Sampling and genotyping}

About $5 \mathrm{ml}$ of whole blood in EDTA anticoagulant were gathered by means of venipuncture under sterile conditions from all participants. Extraction of genomic DNA was performed on peripheral blood leukocytes using a standardized phenol-chloroform technique [31]. The purity of the isolated genomic DNA was quantified spectrophotometrically using Nanodrop 2000c (Thermo Fisher Scientific; USA) and showed that the A260/A280 ratio extended from 1.7 to 1.9 , indicating good quality DNA. The samples were stored at $-20^{\circ} \mathrm{C}$ until analysis. For DNA genotyping, approximately $10 \mathrm{ng}$ of the genomic DNA was used. Genotyping of TYK2 (rs34536443) was performed by the MGB TaqMan allelic discrimination method (Applied Biosystems; USA). All DNA samples were genotyped for rs34536443 by StepOnePlus real-time PCR (Applied Biosystems) according to manufacturer instructions.

\section{Statistical analysis}

Pearson's chi-square test was applied to assess the association of alleles and genotypes with SLE as well as to evaluate the relations of genotypes with the clinical data of the patients. All $P$ values were two-tailed. The odds ratio (OR) and $95 \%$ confidence interval $(\mathrm{CI})$ were also estimated for each allele and genotype. The Benjamini-Hochberg correction method was applied to control for a false discovery rate (FDR) in multiple comparisons [32]. All the statistical analyses were carried out using SPSS for Windows (version 22.0; IBM; USA). SHEsis online software was used for genotype analysis, linkage disequilibrium and the Hardy-Weinberg equilibrium [33].

\section{Results}

One SNP (rs34536443) in 600 SLE individuals and 600 unrelated healthy controls was genotyped. Table 1 presents the clinical specifications of 235 SLE patients.

\section{Allele frequency}

In the NCBI SNP tool, the G allele is used as the reference allele; thus, the frequency of the $\mathrm{C}$ allele was reported (https:/www.ncbi.nlm.nih.gov/snp/?term=rs34536443). As shown in Table 2, the frequency of the $\mathrm{C}$ allele for rs34536443 SNP was $1.70 \%$ in the SLE group, which is same as what was observed in the control group (2.61\%). No significant difference was detected in the allelic distribution of rs34536443 variant between the SLE and control groups $(\mathrm{OR}=0.67, \mathrm{CI}: 0.38-1.17, P$ value $=0.163)$.

Table 2. Allele and genotype distribution of TYK2 gene rs34536443 SNP in SLE patients and healthy controls.

\begin{tabular}{|c|c|c|c|c|c|}
\hline SNP & Allele /Genotype & $\begin{array}{c}\text { SLE }(N=600) \\
N(\%)\end{array}$ & $\begin{array}{c}\text { Control }(\mathrm{N}=600) \\
\mathrm{N}(\%)\end{array}$ & OR $(95 \%$ CI) & Pvalue \\
\hline \multirow{5}{*}{ 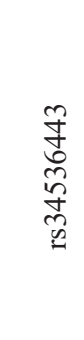 } & $\mathrm{C}$ & $21(1.70)$ & $31(2.61)$ & $0.67(0.38-1.17)$ & 0.163 \\
\hline & G & $1179(98.30)$ & 1169 (97.39) & Reference & \\
\hline & $\mathrm{CC}$ & $0(0)$ & $0(0)$ & - & - \\
\hline & $\mathrm{CG}$ & $21(3.40)$ & $31(5.22)$ & $0.66(0.37-1.72)$ & 0.15 \\
\hline & GG & $579(96.60)$ & $569(94.78)$ & Reference & \\
\hline HWE & & & $P>0.05$ & & \\
\hline
\end{tabular}

\section{Genotype frequency}

At the genotypic level, the GG genotype was assumed as the reference genotype. The heterozygous genotype rs 34536443 CG was observed in $3.40 \%$ of the SLE group and $5.22 \%$ of controls, which was not a significant difference $(\mathrm{OR}=0.66, \mathrm{CI}: 0.37-1.72, P$ value $=0.15)$. The CC genotype could not be detected in either group.

\section{Association between genotypes and clinical features}

We investigated whether or not the rs34536443 genotypes in the TYK2 gene were associated with specific clinical features of SLE patients. Table 3 lists the results. None of the clinical data was significantly different between subjects for the genotypes of GG and CG (none of the subjects were genotyped as CC for rs34536443 SNP). 
Table 3. Various clinical features of RA patients in accordance with the frequencies of 34536443 genotypes.

\begin{tabular}{|c|c|c|c|c|}
\hline \multirow{2}{*}{ Characteristic } & \multicolumn{3}{|c|}{ Genotype } & \multirow{2}{*}{$P$ value } \\
\hline & GG & CG & $\mathrm{CC}$ & \\
\hline Sex & Female $=209$, Male $=18$ & Female $=8$, Male $=0$ & - & $>0.99$ \\
\hline Serositis & $\mathrm{No}=221, \mathrm{Yes}=6$ & $\mathrm{No}=8$, Yes $=0$ & - & $>0.99$ \\
\hline Malar rash & $\mathrm{No}=83$, Yes $=144$ & $\mathrm{No}=5, \mathrm{Yes}=3$ & - & 0.154 \\
\hline Palmar erythema & $\mathrm{No}=207, \mathrm{Yes}=20$ & $\mathrm{No}=7, \mathrm{Yes}=1$ & - & 0.533 \\
\hline Vasculitic ulcers & $\mathrm{No}=212, \mathrm{Yes}=15$ & $\mathrm{No}=8, \mathrm{Yes}=0$ & - & $>0.99$ \\
\hline Discoid rash & $\mathrm{No}=196, \mathrm{Yes}=30$ & $\mathrm{No}=8, \mathrm{Yes}=0$ & - & 0.601 \\
\hline Mucosal lesion & $\mathrm{No}=124, \mathrm{Yes}=102$ & $\mathrm{No}=5, \mathrm{Yes}=3$ & - & 0.734 \\
\hline Photosensivity & $\mathrm{No}=87, \mathrm{Yes}=140$ & $\mathrm{No}=4, \mathrm{Yes}=4$ & - & 0.714 \\
\hline Musculoskeletal arthritis & $\mathrm{No}=62, \mathrm{Yes}=165$ & $\mathrm{No}=3, \mathrm{Yes}=5$ & - & 0.688 \\
\hline Aseptic necrosis & $\mathrm{No}=213, \mathrm{Yes}=14$ & $\mathrm{No}=8, \mathrm{Yes}=0$ & - & $>0.99$ \\
\hline Muscle weakness & $\mathrm{No}=191, \mathrm{Yes}=36$ & $\mathrm{No}=7, \mathrm{Yes}=1$ & - & $>0.99$ \\
\hline Raised muscle enzyme & $\mathrm{No}=201, \mathrm{Yes}=26$ & $\mathrm{No}=8, \mathrm{Yes}=0$ & - & 0.603 \\
\hline Muscle biopsy myositis & $\mathrm{No}=221, \mathrm{Yes}=6$ & $\mathrm{No}=8, \mathrm{Yes}=0$ & - & $>0.99$ \\
\hline Cast & $\mathrm{No}=198, \mathrm{Yes}=29$ & $\mathrm{No}=7, \mathrm{Yes}=1$ & - & $>0.99$ \\
\hline Hematuria & $\mathrm{No}=141, \mathrm{Yes}=86$ & $\mathrm{No}=5, \mathrm{Yes}=3$ & - & $>0.99$ \\
\hline Raised Creatinine & $\mathrm{No}=208, \mathrm{Yes}=19$ & $\mathrm{No}=8, \mathrm{Yes}=0$ & - & $>0.99$ \\
\hline Hypertension & $\mathrm{No}=184, \mathrm{Yes}=43$ & $\mathrm{No}=7, \mathrm{Yes}=1$ & - & $>0.99$ \\
\hline Renal biopsy-Class1 & $\mathrm{No}=227, \mathrm{Yes}=0$ & $\mathrm{No}=8, \mathrm{Yes}=0$ & - & - \\
\hline Renal biopsy-Class2 & $\mathrm{No}=215, \mathrm{Yes}=12$ & $\mathrm{No}=8, \mathrm{Yes}=0$ & - & $>0.99$ \\
\hline Renal biopsy-Class3 & $\mathrm{No}=212, \mathrm{Yes}=15$ & $\mathrm{No}=7, \mathrm{Yes}=1$ & - & 0.436 \\
\hline Renal biopsy-Class4 & $\mathrm{No}=192, \mathrm{Yes}=35$ & $\mathrm{No}=6, \mathrm{Yes}=2$ & - & 0.615 \\
\hline Renal biopsy-Class5 & $\mathrm{No}=215, \mathrm{Yes}=12$ & $\mathrm{No}=8, \mathrm{Yes}=0$ & - & $>0.99$ \\
\hline Renal biopsy-Class6 & $\mathrm{No}=226, \mathrm{Yes}=1$ & $\mathrm{No}=8, \mathrm{Yes}=0$ & - & $>0.99$ \\
\hline Pericarditis & $\mathrm{No}=212, \mathrm{Yes}=15$ & $\mathrm{No}=7, \mathrm{Yes}=1$ & - & 0.436 \\
\hline Cardiomyopathy & $\mathrm{No}=225, \mathrm{Yes}=2$ & $\mathrm{No}=8, \mathrm{Yes}=0$ & - & $>0.99$ \\
\hline Libman sack & $\mathrm{No}=226, \mathrm{Yes}=1$ & $\mathrm{No}=8, \mathrm{Yes}=0$ & - & $>0.99$ \\
\hline Valvular lesion & $\mathrm{No}=193, \mathrm{Yes}=34$ & $\mathrm{No}=7, \mathrm{Yes}=1$ & - & $>0.99$ \\
\hline Ischemic heart disease & $\mathrm{No}=225, \mathrm{Yes}=2$ & $\mathrm{No}=8, \mathrm{Yes}=0$ & - & $>0.99$ \\
\hline Raynaud syndrome & $\mathrm{No}=187, \mathrm{Yes}=40$ & $\mathrm{No}=6, \mathrm{Yes}=2$ & - & 0.636 \\
\hline Thrombophlebitis & $\mathrm{No}=221, \mathrm{Yes}=6$ & $\mathrm{No}=8, \mathrm{Yes}=0$ & - & $>0.99$ \\
\hline Pleuritis & $\mathrm{No}=197, \mathrm{Yes}=30$ & $\mathrm{No}=6, \mathrm{Yes}=2$ & - & 0.299 \\
\hline Lupus pneumonitis & $\mathrm{No}=222, \mathrm{Yes}=5$ & $\mathrm{No}=8, \mathrm{Yes}=0$ & - & $>0.99$ \\
\hline Interstitial fibrosis & $\mathrm{No}=227, \mathrm{Yes}=0$ & $\mathrm{No}=8, \mathrm{Yes}=0$ & - & - \\
\hline Pulmonary hypertension & $\mathrm{No}=225, \mathrm{Yes}=2$ & $\mathrm{No}=8, \mathrm{Yes}=0$ & - & $>0.99$ \\
\hline Embolism & $\mathrm{No}=224, \mathrm{Yes}=3$ & $\mathrm{No}=8, \mathrm{Yes}=0$ & - & $>0.99$ \\
\hline Convulsion & $\mathrm{No}=201, \mathrm{Yes}=26$ & $\mathrm{No}=6, \mathrm{Yes}=2$ & - & 0.244 \\
\hline Psychosis & $\mathrm{No}=222, \mathrm{Yes}=5$ & $\mathrm{No}=8, \mathrm{Yes}=0$ & - & $>0.99$ \\
\hline Peripheral neuropathy & $\mathrm{No}=209, \mathrm{Yes}=18$ & $\mathrm{No}=8, \mathrm{Yes}=0$ & - & $>0.99$ \\
\hline Central involvement & $\mathrm{No}=218, \mathrm{Yes}=9$ & $\mathrm{No}=7, \mathrm{Yes}=1$ & - & 0.298 \\
\hline Raised hepatic enzyme & $\mathrm{No}=54, \mathrm{Yes}=173$ & $\mathrm{No}=1, \mathrm{Yes}=7$ & - & 0.685 \\
\hline Hepatitis & $\mathrm{No}=226, \mathrm{Yes}=1$ & $\mathrm{No}=8, \mathrm{Yes}=0$ & - & $>0.99$ \\
\hline Sjögren Syndrome & $\mathrm{No}=226, \mathrm{Yes}=1$ & $\mathrm{No}=8, \mathrm{Yes}=0$ & - & $>0.99$ \\
\hline Retinitis & $\mathrm{No}=226$, Yes $=1$ & $\mathrm{No}=8, \mathrm{Yes}=0$ & - & $>0.99$ \\
\hline
\end{tabular}




\begin{tabular}{|c|c|c|c|c|}
\hline \multirow{2}{*}{ Characteristic } & \multicolumn{3}{|c|}{ Genotype } & \multirow{2}{*}{$P$ value } \\
\hline & GG & CG & $\mathrm{CC}$ & \\
\hline Leukopenia & $\mathrm{No}=145, \mathrm{Yes}=82$ & $\mathrm{No}=6$, Yes $=2$ & - & 0.715 \\
\hline Lymphopenia & $\mathrm{No}=161, \mathrm{Yes}=66$ & $\mathrm{No}=6, \mathrm{Yes}=2$ & - & $>0.99$ \\
\hline Thrombocytopenia & $\mathrm{No}=182, \mathrm{Yes}=45$ & $\mathrm{No}=5, \mathrm{Yes}=3$ & - & 0.210 \\
\hline Anemia & $\mathrm{No}=157, \mathrm{Yes}=70$ & $\mathrm{No}=5, \mathrm{Yes}=3$ & - & 0.706 \\
\hline Hemolytic anemia & $\mathrm{No}=215, \mathrm{Yes}=12$ & $\mathrm{No}=8, \mathrm{Yes}=0$ & - & $>0.99$ \\
\hline Coombs test & $\mathrm{No}=185, \mathrm{Yes}=42$ & $\mathrm{No}=8, \mathrm{Yes}=0$ & - & 0.357 \\
\hline C Reactive Protein & $\mathrm{No}=76, \mathrm{Yes}=151$ & $\mathrm{No}=2$, Yes $=6$ & - & $>0.99$ \\
\hline FANA & $\mathrm{No}=33, \mathrm{Yes}=194$ & $\mathrm{No}=1$, Yes $=7$ & - & $>0.99$ \\
\hline Anti-dsDNA & $\mathrm{No}=33, \mathrm{Yes}=194$ & $\mathrm{No}=2, \mathrm{Yes}=6$ & - & 0.340 \\
\hline Low_CH50 & $\mathrm{No}=173, \mathrm{Yes}=54$ & $\mathrm{No}=6$, Yes $=2$ & - & $>0.99$ \\
\hline Low_C3 & $\mathrm{No}=124, \mathrm{Yes}=103$ & $\mathrm{No}=5$, Yes $=3$ & - & 0.733 \\
\hline Low_C4 & $\mathrm{No}=115, \mathrm{Yes}=112$ & $\mathrm{No}=6, \mathrm{Yes}=2$ & - & 0.282 \\
\hline Antimalarial drug & $\mathrm{No}=1, \mathrm{Yes}=226$ & $\mathrm{No}=0, \mathrm{Yes}=8$ & - & $>0.99$ \\
\hline Plasmapheresis & $\mathrm{No}=227, \mathrm{Yes}=0$ & $\mathrm{No}=8, \mathrm{Yes}=0$ & - & - \\
\hline Anti-SSA & $\mathrm{No}=225$, Yes $=2$ & $\mathrm{No}=7$, Yes $=1$ & - & $>0.99$ \\
\hline Anti-SSB & $\mathrm{No}=227, \mathrm{Yes}=0$ & $\mathrm{No}=8, \mathrm{Yes}=0$ & - & - \\
\hline Positive anticardiolipin IgG & $\mathrm{No}=222, \mathrm{Yes}=5$ & $\mathrm{No}=7, \mathrm{Yes}=1$ & - & $>0.99$ \\
\hline Positive anticardiolipin IgM & $\mathrm{No}=222, \mathrm{Yes}=5$ & $\mathrm{No}=8, \mathrm{Yes}=0$ & - & $>0.99$ \\
\hline Positive lupus anticoagulant & $\mathrm{No}=224, \mathrm{Yes}=3$ & $\mathrm{No}=8$, Yes $=0$ & - & $>0.99$ \\
\hline Anti- $\beta 2 \mathrm{GP} 1 \operatorname{lgG}$ & $\mathrm{No}=224, \mathrm{Yes}=3$ & $\mathrm{No}=8, \mathrm{Yes}=0$ & - & $>0.99$ \\
\hline Anti- $\beta 2 \mathrm{GP} 1 \operatorname{lgM}$ & $\mathrm{No}=227, \mathrm{Yes}=0$ & $\mathrm{No}=8, \mathrm{Yes}=0$ & - & - \\
\hline IVIG & $\mathrm{No}_{\mathrm{o}}=226, \mathrm{Yes}=1$ & $\mathrm{No}=7$, Yes $=1$ & - & 0.067 \\
\hline
\end{tabular}

\section{Discussion}

As TYK2 appears to be a genetic determinant of autoimmune and inflammatory diseases, the present study hypothesized that TYK2 polymorphism might be involved in the pathogenesis of SLE in the Iranian population. The genotype and allele frequencies of rs34536443 SNP in TYK2 in patients with SLE compared with healthy controls was investigated in relations to the risk of SLE. To our knowledge, this study is the first attempt undertaken to detect this possible association in SLE susceptibility in the Iranian population.

SLE is a complex, systemic autoimmune disease for which a spectrum of modifying and susceptibility genes are responsible for disease initiation and perpetuation. It is widely accepted that several cytokines are involved in the pathogenesis of autoimmune and inflammatory diseases. Numerous studies have suggested a role of cytokines such as IFN- $\alpha$ in SLE development and has been well documented that IFN- $\alpha$ is a pleiotropic cytokine involved in the immunopathogenesis and development of SLE [34-36]. In SLE, IFN- $\alpha$ stimulates a signaling pathway and encoding genes involves molecules on this pathway that may be associated with SLE risk [37].

IFNAR, which lacks intrinsic kinase domains, consists of the transmembrane subunits IFNAR1 ( $\alpha$-subunit) and IFNAR2 ( $\beta$-subunit). TYK2 encodes a proximal tyrosine kinase on the IFN- $\alpha$ signaling pathway and, during antigen stimulation of dendritic cells, induces T-helper 1 differentiation [38]. Upon the IFN- $\alpha$-IFNAR interface, TYK2 interacts with IFNAR1, which results in TYK2 phosphorylation and activation [39]. Activation of TYK2 results in IFNAR phosphorylation and JAK1 activation, which in turn leads to dimerization and activation of the STAT transcription factors. Subsequently, phosphorylated STAT proteins form homo/heterodimers and localize to the nucleus, where they regulate transcription of several genes, including IFN [40].

TYK2 is considered as an interesting candidate for association studies with regard to genetic susceptibility to autoimmune and inflammatory diseases. The association between TYK2 gene polymorphism and autoimmune and inflammatory diseases have been examined in many studies, but the results have been inconsistent $[12,16,19,25$, $26,41,43]$. Some studies have reported a strong linkage of TYK2 haplotypes or individual SNPs with SLE risk [2, $9,16,41]$. The rs34563443 variant of TYK2 alters a conserved proline (major allele) to alanine (protective minor allele) at position 1104 in the tyrosine kinase domain of 
the TYK2 protein, seemingly conferring a functionally less-efficient variant of the TYK2 protein [23]. Moreover, TYK2 function in primary T-cells, fibroblasts and B-cells is affected by the P1104A variant, leading to dysregulated signaling processing of pro-inflammatory cytokines [44].

Peluso et al. reported decreased susceptibility to ERI in Brazilian women due to the C allele of TYK2 rs34536443 polymorphism [11]. Zervou et al. found no significant association between the rs34536443 variant and JIA in the Greek population at either the genotype or allelic levels [45]. Diogo et al. demonstrated that allele C of rs34536443 protects against inflammatory bowel disease (IBD), RA and SLE [44], while others demonstrated that the allele is a risk factor for psoriasis [46] and JIA [47]. Tao et al. (2010) performed a meta-analysis comprising 21,497 cases and 22,647 controls to determine the different variants of TYK2. They demonstrated the association of rs34536443 polymorphism with autoimmune and inflammatory diseases [48]. In this study, the C allele of rs34536443 SNP did not effect SLE susceptibility in the Iranian population, suggesting the role of genetic diversity in different populations and the involvement of different genes in the etiopathogenesis of this multigenic disease.

In the SNP database (http://www.ncbi.nlm.nih.gov/snp/), the frequencies of the $\mathrm{C}$ and $\mathrm{G}$ alleles of rs34536443 were estimated to be 0.01 and 0.99 , respectively. The results in- dicated a frequency for the $\mathrm{C}$ allele in the control group of $2.61 \%$, which is similar to that of the SNP database. Moreover, the frequency of the $\mathrm{C}$ allele in our SLE group was 1.70 , which is similar to those of the control group and the SNP database.

\section{Conclusion}

In conclusion, the current study demonstrated no influence of rs34563443 polymorphism on SLE risk in the Iranian population. It is worth mentioning that in order to reach a definite conclusion, further studies using larger sample sizes are required to determine the exact mechanism by which polymorphisms in this gene result in SLE development. The information from this and related studies should increase understanding of SLE pathogenesis and the possibility of development of promising therapies for the disease.

\section{Acknowledgments}

The authors would like to thank all those who have helped in the completion of this study. This work was financially supported by a grant from the Deputy of Research of Tehran University of Medical Sciences (grant no. 96-0241-35701).

\section{Conflict of interest}

The authors declare no conflicts of interest. 


\section{References}

1. Gregersen PK, Behrens TW. Genetics of autoimmune diseases--disorders of immune homeostasis. Nat Rev Genet 2006; 7(12):917-28. doi:10.1038/nrg1944.

2. Sigurdsson S, Nordmark G, Goring HH, Lindroos K, Wiman AC, Sturfelt G. et al. Polymorphisms in the tyrosine kinase 2 and interferon regula-tory factor 5 genes are associated with systemic lupus erythematosus. Am $\mathbf{J} \mathbf{H u m}$ Genet 2005; 76(3):528-37. doi:10.1086/428480.

3. Sigurdsson S, Goring HH, Kristjansdottir G, Milani L, Nordmark G, Sandling JK. et al. Comprehensive evaluation of the genetic variants of in-terferon regulatory factor 5 (IRF5) reveals a novel 5 bp length polymorphism as strong risk factor for systemic lupus erythematosus. Hum Mol Genet 2008; 17(6):872-81. doi:10.1093/hmg/ ddm359.

4. International Consortium for Systemic Lupus Erythematosus G, Harley JB, Alarcon-Riquelme ME, Criswell LA, Jacob CO, Kimberly RP. et al. Genome-wide association scan in women with systemic lupus erythematosus identifies susceptibility variants in ITGAM, PXK, KIAA1542 and other loci. Nat Genet 2008; 40(2):204-10. doi:10.1038/ng.81.

5. Graham RR, Cotsapas C, Davies L, Hackett R, Lessard CJ, Leon JM. et al. Genetic variants near TNFAIP3 on 6q23 are associated with systemic lupus erythematosus. Nat Genet 2008; 40(9):1059-61. doi:10.1038/ng.200.

6. Cunninghame Graham DS, Manku H, Wagner S, Reid J, Timms K, Gutin A. et al. Association of IRF5 in UK SLE families identifies a variant involved in polyadenylation. Hum Mol Genet 2007; 16(6):579-91.doi:10.1093/hmg/ dd1469.

7. Ronnblom L, Alm GV. Systemic lupus erythematosus and the type I interferon system. Arthritis Res Ther 2003; 5(2):68-75.

8. Villarino AV, Kanno Y, O'Shea JJ. Mechanisms and consequences of Jak-STAT signaling in the immune system. Nat Immunol 2017; 18(4):374-84. doi:10.1038/ni.3691.

9. Cunninghame Graham DS, Akil M, Vyse TJ. Association of polymorphisms across the tyrosine kinase gene, TYK2 in UK SLE families. Rheu-matology (Oxford) 2007; 46(6):927-30.doi:10.1093/rheumatology/kel449.

10. Sato K, Shiota M, Fukuda S, Iwamoto E, Machida H, Inamine T. et al. Strong evidence of a combination polymorphism of the tyrosine kinase 2 gene and the signal transducer and activator of transcription 3 gene as a DNAbased biomarker for susceptibility to Crohn's disease in the Japanese population. J Clin Immunol 2009; 29(6):815-25. doi:10.1007/s10875-009-9320-x.

11. Peluso C, Christofolini DM, Goldman CS, Mafra FA, Cavalcanti V, Barbosa CP. et al. TYK2 rs34536443 polymorphism is associated with a de-creased susceptibility to endometriosis-related infertility. Human immunology 2013; 74(1):93-97. doi:10.1016/j.humimm.2012.09.007

12. Ban M, Goris A, Lorentzen AR, Baker A, Mihalova T, Ingram G. et al. Replication analysis identifies TYK2 as a multiple sclerosis susceptibility factor. Eur J Hum Genet 2009; 17(10):1309-13. doi:10.1038/ejhg.2009.41.

13. Lopez-Isac E, Campillo-Davo D, Bossini-Castillo L, Guerra SG, Assassi S, Simeon CP. et al. Influence of TYK2 in systemic sclerosis suscepti-bility: a new locus in the IL-12 pathway. Ann Rheum Dis 2016; 75(8):1521-6. doi:10.1136/annrheumdis-2015-208154.

14. Lee YH, Bae SC. Association between TYK2 polymorphisms and susceptibility to autoimmune rheumatic diseases: a meta-analysis. Lupus 2016; 25(12):1307-14. doi:10.1136/annrheumdis-2015-208154.

15. Kang EH, Choi JY, Lee YJ, Lee EY, Lee EB, Song YW. Single nucleotide polymorphisms in IL-10-mediated signalling pathways in Korean pa-tients with Behcet's disease. Clin Exp Rheumatol 2014; 32(4 Suppl 84):S27-32.

16. Hellquist A, Jarvinen TM, Koskenmies S, Zucchelli M, Orsmark-Pietras C, Berglind L. et al. Evidence for genetic association and interaction be-tween the TYK2 and IRF5 genes in systemic lupus erythematosus. J Rheumatol 2009; 36(8):1631-8. doi:10.3899/jrheum.081160.

17. Jarvinen TM, Hellquist A, Koskenmies S, Einarsdottir E, Koskinen LL, Jeskanen L. et al. Tyrosine kinase 2 and interferon regulatory factor 5 polymorphisms are associated with discoid and subacute cutaneous lupus erythematosus. Exp Dermatol 2010; 19(2):123-31.doi:10.1111/j.16000625.2009.00982.x.

18. Kyogoku C, Morinobu A, Nishimura K, Sugiyama D, Hashimoto H, Tokano Y. et al. Lack of association between tyrosine kinase 2 (TYK2) gene polymorphisms and susceptibility to SLE in a Japanese population. Mod Rheumatol 2009; 19(4):401-6.doi:10.1007/s10165-0090173-1.

19. Cunninghame Graham DS, Morris DL, Bhangale TR, Criswell LA, Syvanen AC, Ronnblom L. et al. Association of NCF2, IKZF1, IRF8, IFIH1, and TYK2 with systemic lupus erythematosus. PLoS Genet 2011; 7(10):e1002341. doi:10.1371/journal.pgen.1002341.

20. Lee YH, Choi SJ, Ji JD, Song GG. Associations between PXK and TYK2 polymorphisms and systemic lupus erythematosus: a meta-analysis. Inflamm Res 2012; 61(9):949-54.doi:10.1007/s00011-012-0486-y.

21. Tang L, Wan P, Wang Y, Pan J, Wang Y, Chen B. Genetic association and interaction between the IRF5 and TYK2 genes and systemic lupus er-ythematosus in the Han Chinese population. Inflamm Res 2015; 64(10):817-24. doi:10.1007/s00011-015-0865-2.

22. Tao JH, Zou YF, Feng XL, Li J, Wang F, Pan FM. et al. Meta-analysis of TYK2 gene polymorphisms association with susceptibility to autoim-mune and inflammatory diseases. Mol Biol Rep 2011; 38(7):4663-72.doi:10.1007/ s11033-010-0601-5.

23. Mero IL, Lorentzen AR, Ban M, Smestad C, Celius EG, Aarseth JH. et al. A rare variant of the TYK2 gene is confirmed to be associated with multiple sclerosis. Eur J Hum Genet 2010; 18(4):502-4. doi:10.1038/ejhg.2009.195. 
24. Zervou MI, Dimopoulou DG, Eliopoulos E, Trachana M, Pratsidou-Gkertsi P, Andreou A. et al. Tauhe genetics of juvenile idiopathic arthritis: Searching for new susceptibility loci. Mol Med Rep 2017. doi:10.3892/mmr.2017.7733.

25. Dyment DA, Cader MZ, Chao MJ, Lincoln MR, Morrison KM, Disanto G. et al. Exome sequencing identifies a novel multiple sclerosis suscep-tibility variant in the TYK2 gene. Neurology 2012; 79(5):406-11.doi:10.1212/ WNL.0b0133182616fc4.

26. Eyre S, Bowes J, Diogo D, Lee A, Barton A, Martin P. et al. High-density genetic mapping identifies new susceptibility loci for rheumatoid ar-thritis. Nat Genet 2012; 44(12):1336-40.doi:10.1038/ng.2462..

27. Peluso C, Christofolini DM, Goldman CS, Mafra FA, Cavalcanti V, Barbosa CP. et al. TYK2 rs34536443 polymorphism is associated with a de-creased susceptibility to endometriosis-related infertility. Hum Immunol 2013; 74(1):93-7.doi:10.1016/j.humimm.2012.09.007.

28. Tsoi LC, Spain SL, Knight J, Ellinghaus E, Stuart PE, Capon F. et al. Identification of 15 new psoriasis susceptibility loci highlights the role of innate immunity. Nat Genet 2012; 44(12):1341-8. doi:10.1038/ng.2467.

29. Li Z, Gakovic M, Ragimbeau J, Eloranta ML, Ronnblom L, Michel F. et al. Two rare disease-associated Tyk2 variants are catalytically impaired but signaling competent. J Immunol 2013; 190(5):2335-44. 10.4049/jimmunol.1203118.

30. Hochberg MC. Updating the American College of Rheumatology revised criteria for the classification of systemic lupus erythematosus. Arthritis Rheum 1997; 40(9):1725. doi:10.1002/art.1780400928

31. Koshy L, Anju AL, Harikrishnan S, Kutty VR, Jissa VT, Kurikesu I. et al. Evaluating genomic DNA extraction methods from human whole blood using endpoint and real-time PCR assays. Mol Biol Rep 2017; 44(1):97-108. doi:10.1007/s11033-016-4085-9.

32. Benjamini Y, Hochberg Y. Controlling the false discovery rate: a practical and powerful approach to multiple testing. Journal of the royal statisti-cal society Series B (Methodological) 1995:289-300.

33. Shi YY, He L. SHEsis, a powerful software platform for analyses of linkage disequilibrium, haplotype construction, and genetic association at polymorphism loci. Cell Res 2005; 15(2):97-8.doi:10.1038/sj.cr.7290272.

34. Kyogoku C, Tsuchiya N. A compass that points to lupus: genetic studies on type I interferon pathway. Genes Immun 2007; 8(6):445-55. doi:10.1038/sj.gene.6364409.

35. Chasset F, Arnaud L. Targeting interferons and their pathways in Systemic Lupus Erythematosus. Autoimmun Rev 2017. doi:10.1016/j.autrev.2017.11.009.

36. Ronnblom L, Alm GV, Eloranta ML. The type I interferon system in the development of lupus. Semin Immunol 2011; 23(2):113-21. doi:10.1016/j.smim.2011.01.009.

37. Niewold TB, Clark DN, Salloum R, Poole BD. Interferon alpha in systemic lupus erythematosus. BioMed Research International 2010; 2010.
38. Tokumasa N, Suto A, Kagami S-i, Furuta S, Hirose K, Watanabe N. et al. Expression of Tyk2 in dendritic cells is required for IL-12, IL-23, and IFN- $\gamma$ production and the induction of Th1 cell differentiation. Blood 2007; 110(2):553-60. doi:10.1182/blood-2006-11-059246

39. Richter MF, Dumenil G, Uze G, Fellous M, Pellegrini S. Specific contribution of Tyk2 JH regions to the binding and the expression of the inter-feron alpha/beta receptor component IFNAR1. J Biol Chem 1998; 273(38):247239. doi:10.1074/jbc.273.38.24723

40. Platanias LC, Fish EN. Signaling pathways activated by interferons. Exp Hematol 1999; 27(11):1583-92. doi:10.1016/s0301-472x(99)00109-5

41. Suarez-Gestal M, Calaza M, Endreffy E, Pullmann R, Ordi-Ros J, Sebastiani GD. et al. Replication of recently identified systemic lupus erythe-matosus genetic associations: a case-control study. Arthritis Res Ther 2009; 11(3):R69. doi:10.1186/ar2698.

42. Wang K, Zhang H, Kugathasan S, Annese V, Bradfield JP, Russell RK. et al. Diverse genome-wide association studies associate the IL12/IL23 pathway with Crohn Disease. Am J Hum Genet 2009; 84(3):399-405. doi:10.1016/j. ajhg.2009.01.026.

43. Genetic Analysis of Psoriasis C, the Wellcome Trust Case Control C, Strange A, Capon F, Spencer CC, Knight J. et al. A genome-wide associa-tion study identifies new psoriasis susceptibility loci and an interaction between HLA-C and ERAP1. Nat Genet 2010; 42(11):985-90. doi:10.1038/ ng.694.

44. Diogo D, Bastarache L, Liao KP, Graham RR, Fulton RS, Greenberg JD. et al. TYK2 protein-coding variants protect against rheumatoid arthritis and autoimmunity, with no evidence of major pleiotropic effects on non-autoimmune complex traits. PLoS One 2015; 10(4):e0122271. doi:10.1371/journal.pone.0122271

45. Zervou MI, Dimopoulou DG, Eliopoulos E, Trachana M, Pratsidou Gkertsi P, Andreou A. et al. The genetics of juvenile idiopathic arthritis: Searching for new susceptibility loci. Molecular Medicine Reports 2017; 16(6):8793-98. doi:10.3892/mmr.2017.7733

46. Tsoi LC, Spain SL, Knight J, Ellinghaus E, Stuart PE, Capon F. et al. Identification of 15 new psoriasis susceptibility loci highlights the role of innate immunity. Nature genetics 2012; 44(12):1341-48. doi:10.1038/ng.2467

47. Hinks A, Cobb J, Sudman M, Eyre S, Martin P, Flynn E. et al. Investigation of rheumatoid arthritis susceptibility loci in juvenile idiopathic arthri-tis confirms high degree of overlap. Annals of the rheumatic diseases 2012; 71(7):1117-21. doi:10.1136/annrheumdis-2011-200814

48. Tao J-H, Zou Y-F, Feng X-L, Li J, Wang F, Pan F-M. et al. Meta-analysis of TYK2 gene polymorphisms association with susceptibility to auto-immune and inflammatory diseases. Molecular biology reports 2011; 38(7):4663-72. doi:10.1007/s11033-010-0601-5 